\title{
Aoristo)))))
}

International Journal of Phenomenology, Hermeneutics and Metaphysics

\section{Human life and self-realization according to Edith Stein}

\author{
Vita umana e autorealizzazione secondo Edith Stein
}

\author{
Martina Galvani \\ Docente di Storía della filosofía nel Liceo |taliano'
}

\begin{abstract}
The aim of this article is to analyse the Edith Stein's phenomenological-metaphysical anthropology and its moral aspects. Her enquiry shifts from the study of those aspects common to both human beings and animals to an aspect that is specifically and exclusively human, i.e., spirituality. The person only is a spiritual subject, because he has an intellectual knowledge and he can freely act. In this investigation, Stein moves from outcomes achieved thanks to the phenomenological method, which leads her to focus on a description of the bodily, psychical and spiritual sphere of the human being. Accordingly, Stein reflects on the ethical consequences of her anthropological research. Following Augustine, she perceives originary self-consciousness as interiority, from which to begin explicating intellectual knowledge, and especially free action and hence ethics. Action is not only expressed outwards, first of all it is self-actuation - acting and being are mutually implied. The direction of moral actions is thus already present in each one's individual 'essence' (Wesen) and this essence, thanks to the creative 'essentiality' (Wesenheiten), is ab eterno in Logos. In view of this complex theological node, Stein recognizes Christ as the archetype of the only possible ethics.
\end{abstract}

\section{KEY-WORDS}

Phenomenological-metaphysical anthropology; Edith Stein; Human spirituality; Ethic

\section{RIASUNTO}

Lo scopo di questo articolo è quello di analizzare l'antropologia fenomenologico-metafisica di Edith Stein ed il suo aspetto morale. La sua indagine si sposta dallo studio di quegli aspetti comuni sia agli esseri umani che agli animali ad un aspetto specificamente ed esclusivamente umano, cioè la spiritualità. La persona è soltanto un soggetto spiritual, perché ha una conoscenza intellettuale e può agire liberamente. In questa ricercar, la Stein si muove da esiti raggiunti grazie al metodo fenomenologico che la porta a concentrarsi su una descrizione della sfera corporea, psichica e spirituale dell'essere umano. Di conseguenza, riflette sulle conseguenze etiche della sua ricerca

\footnotetext{
${ }^{1}$ E-mail: Martina.galvani8@gmail.com
}

Human life and self-realization according to Edith Stein 
International Journal of Phenomenology, Hermeneutics and Metaphysics

antropologica. Seguendo Agostino, percepisce l'autocoscienza originaria come interiorità, da cui partire per spiegare la conoscenza intellettuale e soprattutto l'azione libera e quindi l'etica. L'azione non si esprime solo verso l'esterno, è prima di tutto auto-attuazione: agire ed essere sono implicati a vicenda. La direzione delle azioni morali è dunque già presente nell'"essenza” individuale di ciascuno (Wesen) e questa essenza, grazie all'"essenzialità" creatrice (Wesenheiten), è ab eterno in Logos. In vista di questo complesso nodo teologico, Stein riconosce in Cristo l'archetipo dell'unica etica possibile.

\section{PAROLE-CHIAVE}

Antropologia fenomenologico-metafisica; Edith Stein; Spiritualità umana; Etica

\section{THE HUMAN RELATION WITH EXTERNAL AND INNER WORLD}

In her reflections, Edith Stein always adopts an ascending approach: setting out from an articulated analysis of psychological life, which becomes discernible through the bodily substratum common to human beings and animals, she comes to free spiritual acts, which can exclusively be exercised by the human person. This argumentation was clear also in Beiträge zur philosophischen Begründung der Psychologie und der Geisteswissenschaften (1922), but in Der Aufbau der menschlichen Person (1932) the point of view is in part different. Indeed, adopting what is a classical as well as phenomenological perspective, here Stein will introduce the concept of "substance" to describe the human soul as subsistent. However, she does not leave the phenomenological inquiry, so she identifies the sensitive (or psychic) soul as the dimension common to all animal beings, including human being. The human soul too is capable of receiving sensory impressions and reacting to them; its openness to external stimuli is correlated with a reactive, instinctual response. But, as the author states, every lower level is transformed by the higher ones; hence, the "mechanism" of reception of the stimuli and the responses that follow upon it take on a different degree of complexity in human being, insofar as they are processed by a spiritual subject. As we will see, that is described through the phenomenological concept of "Persönlichkeit", that is the highest level of the self.

Human beings perceive stimuli objectively, as world structures. For example, colour is always intentionally grasped as the colour of something, and the same holds true for all material qualities. However, human beings are aware of the external stimuli they perceive, meaning that they feel sensorially struck in their body, which is therefore described using the German term Leib. Stein writes:

As a rule, we do not experience sensual impressions (sinnliche Eindrücke) as pure sensory stimuli, but rather as objectively shaped and ordered in the structure of a meaningfully experienced thingly world (STEIN, 2004, p. 74). 


\section{Aoristo)))))}

International Journal of Phenomenology, Hermeneutics and Metaphysics

The various bodily sensations (Empfindungen), received by means of the senses (Sinne), may be associated with different feelings (Gefühle): for example, the perception of strong light through one's eyesight might give rise to a feeling of unpleasantness or annoyance. However, there are also certain feelings that are not necessarily correlated with bodily sensations, as they depend on the connection between body and soul, as in the case of displeasure, freshness, tiredness, and so on. The perceptual life of men, therefore, significantly resembles that of animals: for instance, we use our instinct to assess the things we encounter and our reactions to given stimuli are emotional-instinctual; however, the movements of the human soul - I am not yet referring really to the spiritual sphere here - possess their own specificity, insofar as human beings is capable of becoming aware of them.

That becoming aware means is that the human being is capable of entering into relation not just with the outside - with the world, animals and other human beings - but also with himself. The relation with the external world and that with the inner world influence each other, to the extent that we can assess the former on the basis of the latter, and vice-versa: "That the human being has a double experience of human beings, an inner and an outer, and that both these yet again enter into the unity of experience, that belongs to the human being itself" (STEIN, 2004, p. 76). This double - and specifically human - experience had been identified by Edmund Husserl through the phenomenological method (HUSSERL, 1976b, p. 162-171), that Stein constantly bore in mind in her anthropological investigations. Already in Beiträge this distinction is clear. In fact, here, she describes the egological experiences and nonegological ones; I am conscious of the firsts, because they manifest themselves to the conscience as "vital feelings" (Lebensgefühl), while the "vital states" (Lebenzustand), such as tiredness, vitality, etc., are frequently non-egological and they remain unconscious (cf. STEIN, 2010, p. 43 e ss.).

In this way, are deepened the description of permanent bodily and psychical traits (also called faculties or potencies), which define every living animal and externally manifest themselves through the actual psychic movements: "The actual life of the soul has in the potencies its foundation of being (Seinsgrundlage), the potency goes over into act in another form of being (Seinsform)" (STEIN, 2004, p. 76). So, human specificity is never secondary: although the presence of permanent traits constituting a given temperament is common to every animal being, human beings alone can contribute consciously to the development of these potentialities. This process does not occur spontaneously: it requires the voluntary involvement of the subject, who "actualises" his own potentialities by exercising them, meaning that he realises them by turning them into habitus.

Potencies, habitus and acts all have the same root, namely the unity of the soul (Einheit der Seele), described by the phenomenological concept of "Persönlichkeit": the personal individuality is an unicum, has a limited power (Kraftmaß), which can be developed in one direction or another. Each human being thus emerges as a unitary living whole (einheitliches Lebensganzes) caught in an ongoing process of formation: 


\section{Aoristo)))))}

International Journal of Phenomenology, Hermeneutics and Metaphysics

Psychic and bodily (körperliche) traits are realized as a constant activity that is the outcome of certain abilities and which, at the same time, determines which of the different forms prefigured as possible for the human being will be realized (STEIN, 2004, p. 77).

But what, then, are the conditions for the actualising of human potentialities? External environmental conditions contribute to the full development of living organisms, including plants and animals; if no suitable situations occur, certain capacities of these organisms will atrophy. This also applies to human beings, except that in this case the failure to fulfil certain potentialities largely depends on personal will: human being is responsible for what he will become. In fact, the spirit's potency doesn't act in him only in an unconsciously way, but through his personal choices.

\section{THE SPECIFIC CHARACTER OF THE HUMAN BEING}

Therefore, Edith Stein comes to the description of the specifically human aspect and she develops a concept of spiritual person; she underlines the human capacity of auto-reflection and the consequently capacity of auto-formation: "He can and should form (formen) himself" (STEIN, 2004, p. 78). Only a human being can say "I" - that is, have full self-awareness - insofar as he is a free and spiritual person (freie geistige Person). These traits also become visible in the relation with others. The issue of intersubjectivity had been examined by Stein in Zum problem der Einfühlung (1917) and it remains for her an important theme of study. Here, she uses a compelling example, that of the gaze as a door into the inner self of another person, who is responsible for and in charge of it: "I look in the eyes of a human being and his look answers me. He lets me penetrate into his interior or defends from me. He is lord of his soul and can open or close its doors (STEIN, 2004, p. 78)". A spiritual being is aware of what he is and what he is experiencing, and this awareness is not the product of reflection, but rather an originating, direct kind of knowledge, comparable to a light through which spiritual life itself becomes visible. The originating form of knowledge (die ursprüngliche Form des Wissens) coincides with an opening up inwardly, but also outwardly when an individual relates with others and the exchange is based on the gaze. Stein, therefore, describes human spirituality by using the terms alertness (Wachheit) and openness (Aufgeschlossenhait) (Cf. STEIN, 2004, p. 78)2.

Since the human persons are free, they are spiritual beings, in so far as they can meet things in the world by seeking to uncover their meaning. They are not inevitably driven by instinct or caught in a game of stimuli and responses; rather, they have the power to act according to an established direction and aim. This aspect is better explained by Stein a little later on in the text, by introducing the phenomenological concept of "intentionality", came from Franz Brentano and

\footnotetext{
${ }^{2}$ Here Stein writes: "First of all, we seek to understand spirituality. Personal spirituality means alertness and receptivity. I not only am and not only live, but rather I know about my being and my life. And that all is one".
} 


\section{Aoristo)))))}

International Journal of Phenomenology, Hermeneutics and Metaphysics

studied also by Edmund Husserl. First of all, the intentional movement is understood as the human capacity to approach an object and lend order to the sensible material coming from it, so as to grasp its meaning; in addition, the expression also refers to any action performed in the field of practical choice-making. With this last topic, Stein enters the moral field: every human being - she states perceives a "calling" that he can fulfil through action.

What does it mean that $I$ (Ich) should form (formen) my self (mich Selbst)? Is the I and the self the self-same?" (Cf. STEIN, 2004, p. 80): through these questions Edith Stein is addressing a complex and central issue, which brings together phenomenological investigations and classical findings. Particularly, she is referring to the concepts of free acts theorised by Adolf Reinach. She dialogues also with Thomas Aquinas's thought, indeed she focuses on the relation between the forming "I" and the "Self" that is formed: the I and the Self do not fully coincide and, in order to explain the relation between the two, Stein uses the notions of "form" and "matter". Animal nature represents matter, which in human beings acquires a specific form: that of the "person". As already noted, the psychic life that is common to animals and human beings manifests itself differently in the case of the latter. Sensations are not passively received by person; rather, human being can consciously set his gaze on them, turning them into layers of his living body: "[ $\ldots]$ whenever we fix our gaze on sensations, for us they become the state of our living-body ( $z u$ Zuständlichkeiten unseres leibes)" (Cf. STEIN, 2004, p. 80).

The fundamental form (Grundform) of the psychic human life is therefore intentionality (Intentionalität), which implies the " $\mathrm{I}$ " turned towards an object, the "object itself", and the "act of the I". Indeed, the first meaning of spirit is intentionality. Stein describes the sensations as experiences of the subject in relation with the world through the senses, however she completes the pictures by introducing the issue of intentionality. Perception (Wahrnehmen) occurs through sensory data (Sinnlichendaten) and intentions (Intentionen); therefore, it implies the exercising of human freedom. We thus move on to an analysis of the role of the spirit (Geist), which is capable of intentionally lending order to this sensory material and this capacity is called motivation. While sense-perception (sinnliche Wahrnehmung) is its lowest function, the intellect can reflect on this material and derive its essential structure by means of abstraction, insofar as it is able to act upon it: "The matter which underlies spiritual formation (Formung) is not merely sensual sensation (sinnliche Empfindungen), and the world in which we live is not just a perceived world. The two are connected" (STEIN, 2004, p. 80).

Human beings receive sensations which, as already noted, are associated with different, specific feelings. By intentionally reflecting upon these feeling, they can grasp their "value" (Wert). The world thus shows itself to be a "world of values" (Wertewelt). This issue was already studied by Edith Stein in her doctoral thesis, dedicated to the problem of empathy (Einfühlung), where she discusses with Max Scheler's work: Der Formalismus in der Ethik und die material Wertethik: neuer Versuch der Grundlegung eines ethischen Personalismus. She is interested to the world of values as it is described by Scheler, because this concept can explain the universal human 


\section{Aoristo)))))}

International Journal of Phenomenology, Hermeneutics and Metaphysics

capacity to catch the sense (Sinn) of the things and, especially, to get into the conscience of the other. However, the Einfühlung is not the Mit-fühlen described by Scheler. The phenomenological position of Stein is completely original and the structure of the soul is described as a suitable receptacle for the values, which will affect it to varying degrees of depth and intensity. But even in this process of reception, the soul remains free:

I can follow the lead or not, I can act in either one or another of different possible directions. But also being grasped inwardly offers freedom a starting point: I can give up a peace which rises in me, I can affect the state itself, and I can deny myself this, prevent it, leave it no room. - And finally, a third thing: values not only motivate progress in the context of knowledge, or only a particular emotional response; rather, they are motives, once again in a new sense, they require a particular stance on the part of the will and a corresponding action (STEIN, 2004, p. 82).

At this stage, it is possible to argue that the specific character of the human being for Stein is that he is a spiritual person who acts freely, in a way determining his own form. However, the philosopher asks herself how the two meanings of "form" can coexist: the phenomenological meaning of an I that form a self and the Aristotelian-Thomistic meaning of "form" as the structure of an organism. As regards the first meaning, the I is that point of awareness contained in the soul which, with its potencies and habitus, constitutes the ontological foundation of psychic life. Through its own free actions, the I bestows a given structure upon the psyche, and therefore plays an essential role in the formation of the self. This process of formation occurs at all levels: from the bodily level, through physical exercise, to the psychic one, through the control and development of given inclinations:

The human being is the 'self' with all his bodily-psychic faculties, which I have to form (formen). Yet, what is the I? We have called it a free, spiritual person, and intentional acts are its life. Does the free, spiritual I as such stand outside the bodily-psychic nature which it must form with its action, or does it belong to it, is it its 'inner form'? (STEIN, 2004, p. 83-84).

The I does not lie outside the bodily and psychic nature of the individual, insofar as it is necessarily connected to the living body that it can lend form to even though it is capable of spiritually detaching itself from it. Its action consists in the shaping of the self. Yet, it is impossible to physically locate the I, as it is not a brain cell; rather, it possesses a spiritual meaning (geistigen Sinn) that is only accessible through lived experiences (Erlebnisse). What, then, is the relation between the I, the soul, and the body? To address this issue, Stein resorts to the notion of forma corporis developed by Thomas Aquinas (cf. STEIN, 2014). Following the medieval 


\section{Aoristo)))))}

International Journal of Phenomenology, Hermeneutics and Metaphysics

philosopher, it is possible to argue that the human soul is the form of the living body, insofar as it possesses certain potencies, habitus and an actual life and this is the second meaning of form; yet the soul is also a spiritual soul, which is to say a spiritual substance that subsists independently of the body. Certainly, these two functions of the soul must be grasped as a whole, insofar as we speak of $a$ single soul; the I has the "access" to its own soul (cf. STEIN, 2004, p. 84), but how can we justify all this?

To solve the problem, Stein employs frequently an effective example, where the starting point is once again the phenomenological I: she describes a situation whereby we find ourselves caught in a problem, and external noises and sensory stimuli remain in the background, as our attention is absorbed in what we are dealing with. Even a deep concern will remain latent and confined to the "bottom of my soul" (Grunde meiner Seele), insofar as the focus is on the problem I am pondering. This description of the "layers" of the soul, from the most superficial to the deepest, probably draws upon "depth psychology", which Stein also discusses in the first part of this work and which Edmund Husserl too was very familiar with. She does not speak explicitly about the unconscious, however is clear that there is a dialogue between the nascent psychoanalysis and the phenomenological description of soul proposed by Stein. Moreover, she explains the soul's stratification by drawing a physical analogy with the field of vision. Just as the eye has access only to part of its field of vision, the same is true of the I:

he spiritual field of the gaze is not part of the I, it is something objective, which belongs to the I: it is the objective world, insofar as it is in each case encompassed within its consciousness. The 'central' turning of the I to its theme and 'peripheral' perception are different modes of consciousness (STEIN, 2004, p. 85).

The I, therefore, is a point (Punkt) from which the rays of knowledge fan out, but there is more to the complexity of the substantial soul than the description of the "pure I" - as Husserl had called it (HUSSERL, 1976b, pp. 97-118). The contrast between the surface and the deep concerns the very nature of the soul, which is to say its "inner spatiality" (innere Räumlichkeit), a significant innovation introduced by Stein, thanks to her medieval and Christian studies:

Only a soulish I (seelishes Ich) can be at home; hence it may also be said that it is at home with itself. Then the soul and the I closely come together. A human soul cannot be without an I (eine Menschenseele kann nicht ohne Ich sein): it possesses a personal structure. Yet a human I (ein menschliches Ich) must also be a soulish I, it cannot be without a soul (kann nicht ohne Seele sein): its very acts are characterized as "superficial" or "deep", they are more or less deeply rooted in the soul (STEIN, 2004, p. 86). 


\section{Aoristo)))))}

International Journal of Phenomenology, Hermeneutics and Metaphysics

The I has the deepest point of the soul as its abode, which it acknowledges to be its proper place (eigentliche Stelle). These innovative and original anthropological reflections show also the influence of St Teresa of Ávila and her work El Castillo Interior, which - as is widely known - Stein was very familiar with (cf. STEIN, 2006). The overall description of the soul, which includes a psychological and a spiritual dimension, is completed by identifying the conscious I, which belongs to it and makes the actualisation of the person possible. However, the location of the I within the soul depends on individual freedom. The I is not bound to dwell in the depths of the soul, and may not succeed in fully developing the personal self:

There are things which only be accepted by a certain depth and only from there can achieve the corresponding answer. As long as he (viz. the person) does not delve deep within himself, he is unable to deal with that which is going on inwardly and cannot experience this in an actual way. However, it is a matter of freedom "to search him himself", to rise in his own depth, to grasp itself from there out as a whole and to take in hand (STEIN, 2004, p. 87).

Therefore, does the soul, that has this complex and stratified structure, coincide with form? Stein addresses this Thomistic topic in a very personal way. She briefly draws upon the aforementioned description of the traits of the human soul and adds the phenomenological concept of Lebenskraft, as a quality that varies from human to human. Also other philosopher like Theodor Lipps, Adolf Reinach and Alexander Pfaender have spoken about Lebenkraft, but Edith Stein use this theme in a new way, to indicate the individuality of each human souls. This strength, then, is the defining feature of each individuality, and this essential structure may be regarded as an "inner and substantial form".

Consequently, the soul can rightfully be described as "form", insofar as it not only actualises the inner life of the subject, but in a way also lends form to the living body: "Certainly, one must speak of a formation (Formung) of the living body through the soul; and indeed, in the double sense of formation through the building of the essence and through free action" (STEIN, 2004, p. 87). We have, on the one hand, a specific and original structure of the soul which manifests itself externally and does not depend on the will of the subject and, on the other, the contribution to the formation of the self-provided by the conscious and free I.

The material body (Körper), then, is the material support required for the life of the soul in this world, what makes its external manifestation possible. But not only, in fact the body is also a living body (Leib) and there is no priority of one element over the other: on the contrary, according to Stein body and soul stand in a relation of mutual influence. For example, taking adequate care of the body will make an 


\section{Aoristo)))))}

International Journal of Phenomenology, Hermeneutics and Metaphysics

organism more suited to expressing its spiritual and personal soul. Likewise, conditions of illness or weakness of the living body can make psycho-spiritual activities toilsome, whereas good health can promote them. At the same time, the living body is the matter to which the soul must lend form. However, the formation of the living body through psycho-spiritual life does not have formless matter as its starting point, but rather a Leib which is already formed from the beginning, and on which the spirit is then free to act according to its will. The "movements of the soul" will thus become imprinted upon the physicality of the subject, leaving a particular mark on his character:

In summary we can say: all systematic care and exercising of the body helps ensure that it may become a spiritual livingbody; however, it can be formed only through a spiritual formation (Formung), meaning, first of all, that in it there is a spiritual life which willingly operates so as to lend form (to the body), and, secondly, that the spirit recruits it for spiritual purposes (STEIN, 2004, p. 89).

This does not mean that the body is a material thing that the subject can completely model but, on the contrary, the complex phenomenological concept of Leib allows to describe the person as responsible of his develop, because he lives himself from the inner and he can freely act. In fact, in the process of formation the will (Wille) acquires a fundamental role, insofar as the transition from psychic event to bodily expression can consciously be controlled, because the human being is a spiritual being. No doubt, this transformation implies a will operating at a very deep level and, at any rate, it can only operate within certain boundaries, connected with the initial inclinations and potentialities of the subject. As we have seen, the human being is described in terms of a complex structure consisting of body, psyche and spirit, which develops into a personal structure through the conscious "I" dwelling in the soul. The latter, through the I, voluntarily lends spiritual shape to the actual life of the psychic-bodily subject and directly connected to the role of the will is the question of duty (Sollen).

The free process of formation of the self necessarily unfolds according to a certain criterion, which Stein identifies with duty. In the process of self-formation, duty may be perceived by the subject as an "inner call" (innerer Appell) leading him to do or avoid something. Stein writes:

The 'material' or 'cautionary' conscience perceives the requirements which a particular behaviour entails for us at a given moment and in given circumstances. It requires the free submission of our will. The 'judging' conscience not only judges our action, but tells us something about our being: for a 'good' or 'bad' conscience is not good or bad in itself, but rather testifies to the state of our soul (STEIN, 2004, p. 91). 


\section{Aoristo)))))}

International Journal of Phenomenology, Hermeneutics and Metaphysics

The philosopher further specifies that the call perceived by the individual through his conscience does not correspond to an exhaustive image that needs to be realised: images of this sort can only be grasped in external exemplars that are deemed morally valid. By contrast, the process of actualization of the will in the process of self-formation is free and it is based on particular motivations: "A (genuine or alleged) awareness, an estimation of value based on it, a wish and a decision, and finally an enduring practical behaviour are connected within a motivational context" (STEIN, 2004, p. 92).

With this last theme Edith Stein open the discussion also about the moral anthropology and it becomes clear that her analyse of the singularity concerns an end-structure. The phenomenological view of the philosopher about the human being has also an ethic aspect, that completes her perspective: each individual can follow its "vocation" in terms of the call of the self to its own self-realisation.

\section{3 "MORAL INTERIORITY" AND SELF-REALIZATION}

To enter in the moral anthropology, Edith Stein focuses on the human interiority, that we can call "moral interiority", because - as we will see - the human being is capable to feel the "moral values". The augustinian issue of interiority seems to be the best way to describe this capability of human being to access his inner self and know it. Such inward "opening" is what characterizes the spiritual dimension of human beings (cf. STEIN, 2004, p. 78) and seems to be their maior simitudo with the Creator. If the human soul is spirit according to its most intimate essence, it is by looking at its spiritual determination that we can discover its analogy with God, pure Spirit (cf. STEIN, 2002, p. 460) ${ }^{3}$. The human being, as we have said, is spiritual because is capable of comprehending reality (intellect), but also because he can know himself (memory) and he can act freely (will) (cf. STEIN, 2002, p. 362). The phenomenological investigation is enriched with Augustine's description of the spirit (mens in Latin) as intellect, memory and will. Phenomenology defines spiritual life as an "intentional movement" by which the subject looks at an object (cf. STEIN, 2010, pp. 64 ss.) and considers it according to a specific meaning content (Sinnesgehalt) ${ }^{4}$, through the essentialities (cf. STEIN, 2002, chap. IV). According to Stein, this human spiritual knowledge is toward the external world and it is toward the inner world. So thanks to his spiritual being, man can look also inwards - in interioritate - and know himself. This spiritual self-knowledge capacity - i.e. interiority - is however limited, as it is not totally clear to oneself. Indeed, the spiritual soul is characterized by interior light and darkness, similar to "a lighted surface over a dark abyss" (cf. STEIN, 2002, p. 365).

\footnotetext{
${ }^{3}$ Differently from this translation, I will use the term "essence" for Wesen and "essentiality" for Wesenheit.

${ }^{4}$ In the phenomenological description, the spiritual capacity to grasp intentionally an object it's thanks to the "motivation".
} 


\section{Aoristo)))))}

International Journal of Phenomenology, Hermeneutics and Metaphysics

Therefore, the spiritual life is self-knowledge, namely interiority, and finally it is free will (cf. STEIN, 2002, p. 372)5. Thanks to the latter, the subject can be defined as a "person". He can freely choose how to act and thus pronounce his fiat. This ethics issue, about appetitive faculty, is discussed by Stein in her anthropological description, which we can define as phenomenological-metaphysical (ALES BELLO, 2007, p. 15). According to Stein, this faculty is oriented towards good. The desire for good which is characteristic of the spiritual dimension is explained starting from the thomistic discussion on transcendentals, especially the transcendental bonum. Willing the good implies knowledge; what is willed is known, and therefore true (cf. STEIN, 2002, p. 312). Bonum and verum are closely related and - like in Thomism - they impart perfection to the existent (ens) (TOMMASO D'AQUINO, 2012, q. 21, a. 1 and a. 3). The spirit can understand reality because it grasp its essence, and thus essentiality. We enter the topic of archetypes, understood not as something different from the real-actual being, but rather as the existent in its actualization: "the existent as it should be" 6 . The cognitive faculty (intellect) and the appetitive faculty (will) are seen in their mutual determination and the classic theory of transcendentals is integrated with the contemporary "value theory". Stein writes: "[...] which we call value belongs to the realm of essential being. It is pre-designed from eternity not only what an existent (ens) is, considered in itself, but also what significance, i.e., what value, attaches to it in the total context of all existents" (cf. STEIN, 2002, p. 316).

The human beings, as real-actual existent, are subject to becoming and, acting freely, can tend to the realization of what they are essentially. Unlike the pure Act, in them being and acting do not coincide, but there are potentialities in interioritate which can be realized in time (cf. STEIN, 2002, p. 376). In this sense, we can use the word "moral interiority" to indicate the person as capable of feeling the values and realizing what he is essentially. Only as free to "create" his life can the subject be defined as a person. This freedom of self-determination is however a gift that man has received and that can be developed in any freely chosen direction.

\section{DEUS TRINITAS AS THE FOUNDATION OF MORALITY}

We have seen that man is an actual-real person: his essence can be freely actuated in existence, in a temporal process. However, what is actuated in such process is since eternity. We have finally explained this apparent contradiction. With Stein, we can say that the sense, actuated through this becoming process, is fully

\footnotetext{
${ }^{5}$ Stein writes: "The realm of spiritual life is the authentic realm of freedom. Here the I can be genuinely creative out of the depth of its own self. What we call free acts - a firm resolve, the voluntary inception and execution of some action, the explicit turning toward a "rising" thought, the conscious termination of a succession of idea sas well as all questioning, demanding, granding, promising, commanding, obeyding- are deeds" of the I, manifold in their meaning and inner structure, but uniform in one respect. In all of these deeds the I determines the content or direction of its own being [...]. This does not mean, of course, that in these deeds the I becomes [...] the creator of its own self. The I has received the freedom of self-determination as a gift".

${ }^{6}$ About this theme, Stein describes the difference between human being and angelic creature: cf. STEIN, 2002, chap. VII, §5.
} 


\section{Aoristo)))))}

International Journal of Phenomenology, Hermeneutics and Metaphysics

contained in the Logos, beginning and origin of this fullness of meaning. No contingent entity can exist outside the absolute and eternal Being - it would be a logical contradiction. The temporal becoming of the real being, and therefore of human existence, is based upon what Stein called "the realm of meaning" (cf. STEIN, 2002 , p. 150) to which every meaningful unit belongs. These units, however, receive meaning as a gift in the creative act, that is not temporal. Since in God being and action coincide, there is no beginning in the creation act. It cannot be conceived with the temporal categories which characterize human production. Created beings are called into existence in time, but they are in their meaningfulness since eternity, according to their essentiality. From this point of view, Stein interprets the first verse of the Prologue to St. John's Gospel as "in the beginning was the meaning (Im Anfang war der Sinn) ${ }^{7 "}$. And then: "through him all things came into being" 8 . The generation of the Word through the Father expresses His real-actual being. In fact, the Logos is a real person. However, His existing is not separated from His essential being, since in Him there is no beginning. This generating act, which is eternal and in God Himself, already contains the whole creation; there is no before or after. The archetype problem, again. How can we solve it? What role should this topic play in the moral perspective we have outlined? This passage of the Scriptures, says Stein, prompts us to return to Augustine's theory of ideas as "creative essentialities in the spirit of God".

How is the con-stare of things, their subsisting or being alive in the Logos, to be understood? It has been pointed out that it cannot be understood as their actual being. [...].The name Logos seems to indicate that what is meant might be the essential being of things, that the meaning of things (which we have previously characterized as "not-become" [ungervworden]) might have its habitat in the divine Logos. That which from eternity subsists a component part [Glied] of the divine plan of Creation is "imparted" to things as their meaning and is actualized in them (STEIN, 2002, p. 114).

The creative essentialities are in Him, because "through him all things came into being". The interpretation of the above passages, however, should not lead us to posit that essentialities in the Logos are previous to their realization hic et nunc. Essentialities are in fact already real-actual in Him, ab eterno. In this sense, they are defined by Stein "creative archetypes". She writes: "[...] the being of the finite in the eternal carries a twofold meaning: 1 ) a being-encompassed of all finite things by the divine spirit and 2) a causal being-founded on all finite things in the divine essence" (STEIN, 2002, p. 116). These considerations lead to the problem of individuation, which we cannot examine here. However, we would like to note that, if the

\footnotetext{
${ }^{7}$ Der Sinn is often traslated as "meaningful existence" (cf. STEIN, 2002, p. 106).

${ }^{8}$ Cf. St. John 1, 1-18.
} 


\section{Aoristo)))))}

International Journal of Phenomenology, Hermeneutics and Metaphysics

individual essence has a twofold aspect - essential quid and full quid - it could be a good starting point to try and solve the apparent contradiction between unity and multiplicity. Essence is the quid of each actual-real entity (full quid), and at the same time is contained in the Logos since, participating in essentiality, is in the Logos as not other from Him, and at the same time with its specific individual being. According to Stein, from this point, it is possible to enter the mystery of the twofold Revelation of the Logos: in the incarnate Word and in the created world (STEIN, 2002, chap. III, $\S 12)$.

The Word, i.e. Christ, becomes therefore the only possible archetype, for each action. He is the medium who solves the seeming contradiction between One and many. If the creative archetype is the actual-real being "as it should be", since it is its origin and thus its most authentic being 1) and if such archetype is present since eternity in the Logos made flesh in Christ 2) then the "model" of each action can only be the living God made human. No ethical argument is therefore possible outside the imitatio Christi as a moral model. What we have called "moral interiority" is the individual's capacity to feel the values and the try to realize at best themselves. This self-actualization is possible only thanks to the love which originates in the Word made human. What can be realized morally is in the individual's interiority, what Augustine called the place of eternal truths. The path to impart perfection to oneself - the natural pining for good characteristic of appetitive faculty - is in free human action, preceded by knowledge and expressed with love. This ethics perspective, metaphysically and theologically founded, finds its explanation in the mystery of the Trinity. Only with the Trinity as a model can we understand ethical life as the realization of love, says Stein (cf. STEIN, 2002, chap. IV, §4 and §5). Indeed, the relation between a finite " $\mathrm{I}$ " and a finite "you" can only be imperfect, since in the "we" there is an irresolvable difference of essential and existential. It is not so in the Trinity, where three People are linked by a perfect identity of essence. The "we", in the Trinity, is relation between People and at the same time full unity ${ }^{9}$. Here, the relation is a total love gift, where the I gives itself totally to the you in the act through which the Father generates the Son and breathes with Him the Holy Spirit. It is a mutual gift of a single eternal infinite essence between Divine People. Writes Stein (2002): "This essence and being the Father gives from eternity to the Son by generating him, and from this gift proceeds, as the fruit of mutual love, the Holy Spirit" (p. 351).

\section{CONCLUSION}

To conclude we can say that thanks to the fact that the human being is a spiritual creature and can open himself to himself, he can intellectually grasp the meaning of reality and act in it. Following Augustine, Stein perceives this original consciousness of oneself (interiority) as "an inner place, not a place" ("interiore loco, non loco"), the

\footnotetext{
${ }^{9}$ The Holy Trinity is full spirit, namely total gift of love. For analogy, the human spiritual dimensioni s capacity to give itself: cf. STEIN, 2002, chap. VII, §2.
} 
International Journal of Phenomenology, Hermeneutics and Metaphysics

starting point for an explanation of intellective knowledge, but especially the free acting and consequently ethics and, consequently, ethics.

Action is not just expressed outwards: it is first of all self-actuation. Acting and being are mutually implied. The direction of moral actions - as will of perfection - is thus already present in the essence of each individual and this essence, thanks to the creative essentiality, is ab eterno in the Logos.

\section{REFERENCES}

ALES BELLO, A. Edith Stein: lo spirito umano in cammino verso la santità. In: Edith Stein. Lo spirito e la santità. Org. (Michele D'Ambra). Roma: Edizioni OCD, 2007.

HUSSERL, E. Ideen zu einer reinen Phänomenologie und phänomenologischen Philosophie. Erste Buch: Allgemeine Einführung in die reine Phänomenologie, Karl Schumann (Hrsg.), Nachdruck 1976, "Husserliana III". Trad. Enrico Filippini. Idee per una fenomenologia pura e per una filosofia fenomenologica. Libro primo: Introduzione generale alla fenomenologia pura, Torino: Einaudi, 2002. . Ideen zu einer reinen Phänomenologie und phänomenologischen Philosophie. Zweites Buch: Phänomenologische Untersuchugen zur Konstitution, Walter Biemel (Hrsg.), Nachdruck 1976, "Husserliana IV". Trad. Enrico Filippini. Idee per una fenomenologia pura e per una filosofia fenomenologica. Libro secondo: Ricerche sopra la costituzione pura, Torino: Einaudi, 2002. LAVIGNE, J.-F.. Anima, corpo, spirito in Ripensando I'umano: in dialogo con Edith Stein, (Org.) Angela Ales Bello, Nicola Zippel. Roma: Castelvecchi Editore, 2015 STEIN, E. Finite and Eternal Being: An Attempt at an Ascent to the Meaning of Being. Trad. Kurt F. Reinhardt. Whashington: Institute of Carmelite Studies, 2002.

. Der Aufbau der menschlichen Person. Vorlesung zur philosophischen Anthropologie, ESGA 14. Freiburg im Breisgau: Verlag Herder, 2004. . Die Seelenburg, im Endliches und ewiges Sein. Versuch eines Aufstiegs zum Sinn des Seins, ESGA 11/12. Freiburg im Breisgau: Verlag Herder, 2006. . Beiträge zur philosophischen Begründung der Psychologie und der Geisteswissenschaften in Jahrbuch für Philosophie und phänomenologische Forschung, ESGA 6. Freiburg im Breisgau: Verlag Herder, 2010.

. Husserls Phänomenologie und die Philosophie des heiligen Thomas von Aquino. Versuch einer Gegenüberstellung, in Festschrift Edmund Husserl zum 70. Geburstag gewidmet. Ergänzungsband zum Jahrbuch für Philosophie und phänomenologische Forschung. In "Freiheit und Gnade" und weitere Beiträge zur Phänomenologie und Ontologie (1917-1937), ESGA 9. Freiburg im Breisgau: Verlag Herder, 2014, pp. 119-142.

TOMMASO D'AQUINO, Somma teologica. Trad. Frati Domenicani. Bologna: Edizioni Studio Domenicano (ESD), 2012.

Submitted: June 4, 2021

Accepted: July 2, 2021 